SECTION 13. Geography. History. Oceanology. Meteorology.

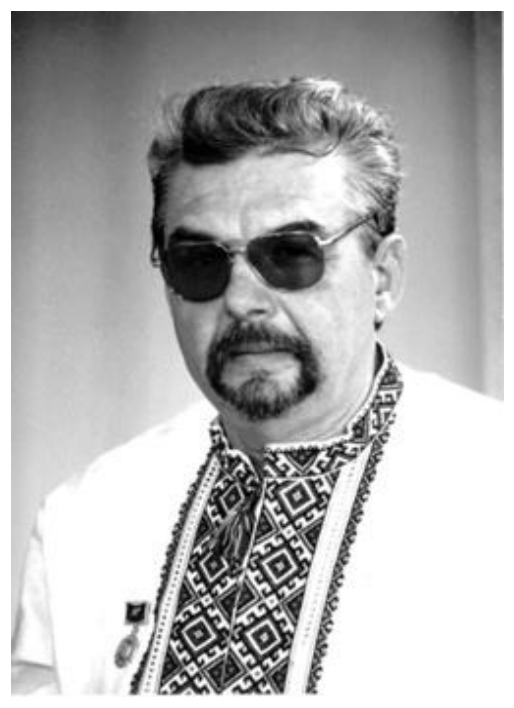

Tatarinov Sergey Iosifovich candidate of historical Sciences, associate Professor, Educational and Scientific Professional Pedagogical Institute of Ukrainian Engineering and Pedagogical

Academy

\title{
BAKHMUT MERCHANTRY IN THE SYSTEM OF ZEMSKY SELF- GOVERNMENT AND DONBASS'S ECONOMY MODERNIZATION (XVIII- BEG. XX CENT.).
}

The role of the merchants of the largest county of the Russian Empire in the development and modernization of the economy of Donbass region is examined for the first time.

Bakhmut merchants played a significant role in the trade of salt, vodka and agricultural products in the 18th century.

Merchants' capital helped to develop the wholesale trade fairs in Yekaterinoslavsk gubernia, so the county had the highest number of fairs.

The building materials manufacturing, agro-processing, retail trade in stores were the founding spheres of merchants' capital in the second part of the 19th century.

A significant part of the merchant class and the Bakhmut county life was taken by Jews.

The merchants were actively involved in the local government activities such as county rural convocation and the Bakhmut city Duma.

Key words: merchant, guild, fair, patent, justice, the Duma.

\section{УДК 94 (045/046)}

\section{БАХМУТСКОЕ КУПЕЧЕСТВО В СИСТЕМЕ ЗЕМСКОГО САМОУПРАВЛЕНИЯ И МОДЕРНИЗАЦИИ ЭКОНОМИКИ ДОНБАССА (В ХVIII- НАЧАЛЕ ХХ СТОЛЕТИЙ).}

Впервые исследуется роль купечества крупнейшего уезда Российской империи в развитии и модернизаџии экономики Донбасса. 
Купиы Бахмута уже в 18 столетии играли значительную роль в торговле солью, водкой, продуктами сельского хозяйства.

Купеческие капиталь способствовали развитию оптовой ярмарочной торговли в Екатеринославской губернии, поэтому в уезде было наибольшее число ярмарок.

Сферами проложения купеческих капиталов во 2-й половине 19 столетия были производство стройматериалов, переработка сельхозпродукиии, рознично-магазинная торговля.

Значительное место среди купечества Бахмута и уезда занимали евреи.

Купиь активно участвовали в деятельности земских органов самоуправления-уездном земском собрании и Бахмутской горордской Думе.

Ключевые слова: купеи, гильдия, ярмарка, патент, управа, Дума.

Постановка проблемы. Влияние купечества как движущей силы среднего и малого бизнеса недостаточно изучено в постсоветских исследованиях, хотя закономерности становления и развития купечества как сословия, принципы его продуктивной деятельности актуальны сегодня как пример создания основы для возникновения т.н. «среднего класса».

Анализ актуальных исследований и публикаций. К сожалению, в советское время эта тема не разрабатывалась, в независимой Украине также осталась вне внимания историков и экономистов. Анализ роли купечества в развитии и модернизации Мариупольского, Бахмутского и Славяносербского уездов Донбасса (согласно исследованию японского историка Г.Куроми [1] ) отсутствует. Частично этого вопроса коснулись А.Оглоблин \{2], В.Ляшенко [3], автор статьи [4].

Цель статьи состоит в привлечении ранее неизвестных источников по истории купечества и анализе его влияния на развитие различных предприятий и торговли в Донбассе.

Изложение основного материала. В крепости Бахмут в 30 годы XVIII века находились магазин для хлеба, «судейская изба», амбар для соли деревянный, каменный погреб для казны, деревянный купеческий Постоялый Двор. В Бахмуте проживали из гражданского населения купцов 144 с 138 членами семейств ( евреев 21), мещан 492 (евреев 69)[5].

В середине XVIII столетия указывалось, что дворов в городе 252, мужчин 322, женщин 295. «В оном городе купцы имеют свой торг не в одном своем, но и в других городах разными шелковыми, шерстяными и пушными товарами, закупают разный скот, а некоторые упражняются в хлебопашестве. Торговые дни бывают в воскресенье и пятницу, ярмарок две: 1-й - в День Петра и Павла, 2-й - в Рождества Богородицы, на которые прибывают из разных городов с товарами, пригоняют лошадей и скот»[5]. 
В Описании Бахмутского благочиния указано, что «город разделяется на три квартала. Партикулярных, обывательских разного звания людей и чинов домов каменных 1, деревянных 583. Разного звания людей и чинов, кроме воинских Бахмутского батальона, живущих в городе 960 мужчин и 845 женщин. Живущие купцы и мещане торговлю производят во внутренних городах. Всякого года бывает два ярмарка ...и продолжаются не более 3-х дней».

В Бахмуте торговали крымские татары, ногайцы, калмыки, которые привозили сырые шкуры, баранину, а покупали хлеб. Купцы составляли значительную часть населения города-крепости.

В разные периоды численность купцов в Бахмуте менялась.

«Город Бахмут при самом пограничном месте степном и лесов поблизости нет, и река Бахмут наименьший приток имеет, а в сухменное лето пересыхает. От Оттоманской Порты, от Крымской области поставляется от города залога в прошлых годах от враждебного нападения, от турок, крымских и кубанских татар, азовских башлеев от коих сжигание хуторов, разворовывание и грабежом всяких имений и выгоном коней и скота... варварство на здешних степях около города смертным убийством, чрезвычайным мучительством, пленением обоего пола людей, часто заносятся с крымской стороны моровые эпидемии...купцы за невыпуском из города в смертном страхе и отчаянии» - писали Екатерине II «торговые люди» о своих проблемах в Наказе 1767 г. [6].

Купцы с приказчиками и слугами входили с оружием в гарнизон, участвовали в обороне, поставляли пищу, участвовали «в погоне с оружием и запасами с легкими войсками». Саранча выедала посевы, город имел недостаток хлеба. Купцы понесли убытки от заболевания скота и пожаров 1764 года в Бахмуте и в 1765 году в Луганской станице. Купцы содержавали крепостной батальон, несли убытки, разорялись, не могли платить вовремя подушную подать казне [6] .

«Выборные граждане» Бахмута - президент и городской голова Тимофей Назаров, бургомистр Осип Грошев, ратман Петр Михайлов, гражданский староста Иван Четвериков, купец Парфен Гаврилов и еще 30 купцов... составили 11 «кондиций» для Екатерининской Комисии в Москве. Просили занятые купцами земли по реке Бахмут с хуторами, мельницами, пашней и сенокосами закрепить за ними и никому не продавать в дальнейшем. При разграничении земель уезда около Бахмута свободные земли позволить покупать купцам. Позволять им приобрести крепостных- 1-й гильдии по 10 душ, 2-й 6 душ, 3-й по 3 души, переселять на пахотные земли магометан башкир и татар, переходить им к другим хозяевам запретить. Платить купцам за них обычную подушную подать и к обороне крепости при набегах привлекать. Позволить купцам покупку земель под заготовку дров для винокурения и установить обычный акциз с ведра водки. Позволить брать дрова и хворост в лесах по Донцу и по 
Казенному Торцу для солеварения в Бахмуте и Торе, отопления в домах. Освободить купцов от выборов голов и целовальников в других городах, рекрутов у них не брать.

Соляная контора отдала питейное дело купцу Парфину Гаврилову, после окончания срока следовало отдать Магистрату право распределять продажу водки и вин между купцами.

Купцы просили ввести независимого от Магистрата квартирмейстера, поручить ему ставить на постой проезжающих военных. Купцов освободить от постоев гарнизонной команды, артиллеристов и инженерной части.

Купцам иногородним торговать только с разрешения Магистрата и позволить записывать детей в купеческое сословие [6] .

Купец Василий Терентьев обратился к Азовскому губернатору с просьбой отдать Бахмутский соляной промысел ему в аренду. К губернатору вызвали коменданта полковника Ивана Шабельського, который указал на невозможность возобновления солеварения и недопустимость уничтожения лесов по Донцу [7].

В докладной записке губернатору Бахмутский комендант И. Шабельский писал: «город лежит между двумя горами в низменном месте. Купцов 168, мещан - 138, цеховых - 21, разного звания жителей - 1437. За год проходит 4 ярмарки: феврале в день Сретения Господнего; июне в день апостолов Петра и Павла; сентябре в день Рождества Богородицы; ноябре в день великомученицы Екатерины, длятся дней по пяти» [8].

В 70 годы XVIII века «рыбы в реках и озерах довольно, земля плодоносная и большею части обработана. Жители упражняются в хлебопашестве, скотоводстве и торговле, получая достаточную вот сих упражнений прибыль» [9].

В 1799 году каждый третий горожанин из торгового состояния (из 1089 жителей - 167 купцов), купцы «имеют торг не в одном только своем, но и в других городах», торговали «разными шелковыми, хлопчатобумажными и из пушнины товарами», продукцией крестьян [10].

Самыми состоятельными купцами Бахмута в конце XVШ века были Тимофей, Федор и Иван Назаровы, Осип Грошев, Иван, Федор, Андрей Четверикови, Петр Михайлов, Парфен Гаврилов, Никита Болотов, Иван Брянцев, Елисей Масленников, Леон Ложкин, Степан Часов, Василий Терентьев, Прокопий Фомин, Прокопий Минаев, Алексей Печников, Дмитрий Скоробогатов, Василий Жаров, Андрей Кузьмин, Иван Фролов, Андрей Курдюмов, Леон Костылев, Федор Васильков, Григорий Урсиков, Спиридон Станкович, Леон Савельев, Степан Гнутов, Иван Косолапов, Василий Бобров, Родион Криворотов, Павел Лобас (Лобасов).

До конца XVIII века в крепости Бахмут, вероятно, был Гостинный Двор, с 1808 года торговые лавки распространяются по городу.

Бойни и торговля мясом велись на берегу р. Бахмут [11]. 
В 1829 году в Бахмуте было 4215 жителей, 92 купцов [12].

Роль торгового центра уезда требовала от Бахмута соответствующей застройки.

Первый план застройки Бахмута был составлен в 1783 году. После пожара 1815 года архитектору Гесте правительство поручает составить новый генеральный план. В 1823 году Александр I конфирмовал проект Гесте решил переместить строения Гостиного Двора к северу от Троицкого собора, что вызвало длительные споры и переписку городских ратнеров с наместником Новороссии графом М.С.Воронцовым и МВД [4].

В 1831 году измененный план застройки был утвержден Николаем I. Гостиный Двор был построен из кирпича, с декоративными деталями (хорошо видными на фотооткрытках начала XX века), напоминал Пассажи Костромы, Ярославля, Нижнего Новгорода. Он имел вид квадрата из зданий полутораэтажной застройки, 52 «лавки» со складами [4].

«Сословие купеческое имеет отличительный характер от великороссийского купечества, по своей разноплеменности и степени образования. Здесь есть купцы малороссияне, греки, армяне и евреи. Не смотря на одинаковый образ занятий, каждое из этих племен имеет особенности, заметно различающих их между собой. Купцов из Великоросси здесь гораздо более в уездных городах, чем малороссиян, хотя в народонаселении малороссийское племя значительно преобладает. Это доказывает, что в характере малороссиян мало побуждений к промышленным предприятиям. Образ жизни купцов-великороссиян совершенно сходен с образом жизни людей того же сословия и племени во внутренних губерниях империи; только в образовании, кажется, они еще несколько отстали» ]13].

В 1835 году в Бахмуте 6550 жителей, домов кирпичных 6, деревянных 1017, церквей 5, лавок 30, винных погребов [5].

В 1839 году в уезде проходили ярмарки: в Бахмуте на 4-е воскресенье Большого поста, Петропавлавская, Богородичная; в Луганском 3 ярмарки; Александровке 4 ярмарки; в Голициновке 4 ярмарки, в Селидовому, Андреевке, Казенно-Торском по одной [14].

В 1846 году в Бахмуте 6442 жителя, 1987 домов, 3 гостиницы и 6 Постоялых Дворов, 4 кирпичных, 8 салотопельних, 3 сальных свеч заводов. В 1848 году были ярмарки Великопостная (продажа товара на 73 тыс. рублей), Петропавловская (продажа на 90 тыс.рб.), Рождественскобогородичная (продажа на 48 тыс.рб.), каждая длилась 5 дней [15].

В 1853 году в Бахмуте 7377 жителей, 1867 домов,, 3788 десятин городской земли, действовали 2 гостиницы, 6 постоялых Дворов, 4 винных склада, 2 парикмахерских, 2 каретных мастерских, паровая и 32 ветряных мельниц, 21 кузница, 48 кирпичных магазинов [16]. 
Органом местного самоуправления мещан, купцов в 40-е годы X1X ст. был Магистрат, который возглавлял купец 3-ї гильдии Дмитрий Андрианович Карталов, секретарь П. А.Коровиченко [16].

Бургомистрах состоял из 2 бургомистров, 4 ратнеров, стряпчего, протоколиста, повитчиков 2, архивариуса.

Для оформления оптовых торговых и имущественных соглашений и договоров мещане и купцы избрали маклером-нотариусом титулярного советника Василия Масленникова[16].

В 1850-55 годах большие ярмарки происходили в волостных селах Луганское, Железное, Гришино, Ясиноватое, завозилось товаров на 190 тыс.рб., продавалось на 62 тыс.руб. [17].

В 1857 г. «в городе 9197 жителей, 376 дворян, 169 лиц церковного причта, 774 купцов, 4533 крестьян». Заводы свечной (продукции на 5000 руб.), салотопных 6 (продукции на 19 тыс. рб.), мыловаренный (продукции на 4000 руб.), восковой, кирпичных 5 (продукции на 63 тыс.руб.). Пивоваренные заводы были у Ильиновке, Дедино, Карловке, Смоляниновке. Суконная и кашемировая мануфактуры Папкова в Красном Куте. В Бахмуте работали 562 ремесленника. Добыча известняка велась по аренде в нескольких местах за 625 руб.серебром в год [18].

В 1858-59 гг. в городе Бахмуте было 8367 жителей, домов 1882. Функционировали 2 гостиницы, 6 Постоялых Дворов, каменных магазинов 38 , водочных 5, каретных мастерских 3, механических мельниц 4 и ветряных 34 , кузниц 27 , кирпичных заводов 5 , салотопных 10 , свечной и восковой, известняковых 3. Город имел 36 колодцев [18].

В 1860 году в городе 12409 жителей. Бюджет Бахмута составлял 8272 рублей (обычные доходы 7709, чрезвычайные 562 рублей), расхода 6072 рублей ( капитал резервный 359 руб., запасный 2219 рублей) [18].

Торговля на ярмарках в 1856-60 гг. в Бахмуте была прибыльной. Средопостная ярмарка (привоз на 45 тыс.руб., продажа на 38 тыс. руб.), Петропавловская (привоз на 125 тыс.руб., продажа на 40 тыс.руб.), Рождественская (привоз на 65 тыс.руб., продано товаров на 56 тыс.рб.) [18].

В I-й половине XIX века известны купцы братья Илларион и Андрей Першины, Савва Косенко, Матвей Стрелин, Василий Троянов [19].

«Ярмарки имели вид установленных на площади балаганов приезжих купцов, но ставили шатры и местные, хоть магазины были почти рядом...Ко времени открытия ярмарки простонародье обыкновенно уже собрано... и съезжаются окрестные помещики со своими семействами для закупки всех необходимых домашних потребностей, в числе которых на первом месте женские наряды. В хорошее время съезд помещиков бывает значительным. По самому положению города, стоящего в центре огромного пространства, на котором нет ни одного порядочного торгового пункта...многие приезжают с единственной целью провести хорошо 
время. Особенных покупок не делают, оставляют немалые деньги в городе. В это время появляются конный цирк, зверинец, иногда театр. В саду каждодневно в ротонде играет музыка и собирается лучшее общество...В винных лавках продавцы товаров оставляли почти половину своего выторга» [18].

Цены на товары были (за пуд) : печеный пшенишний хлеб 1,6 руб., житный 1,2 руб., говядина, мелкая рыба 2,2 руб., масло растительное 4,2 руб., соль «крымка» 4,6 руб.

С 1861 года в Екатеринославской губернии ярмарок было 125, городских-11 с общим оборотом 3,5 млн. рублей серебром [18].

Широкой была ярмарочная оптовая торговля в Бахмутском уезде, составлявшем большую половину нынешнего Донбасса. В 1860-62 гг. в наиболее крупных волостных селах было до 80 ярмарок. В Ясиноватом: Великопостная ярмарка (привоз на 26 тыс. рб., продажа на 10 тыс. рб.), Николаевская (привоз на 34тыс.рб., продажа на 6 тыс.), Покровская (привоз на 27 тыс. рб., продажа на 10 тыс.). В Лисичанске: Похвальная ярмарка (привоз на 31 тыс.рб., продажа 12 тыс. рб.),Николаевская в мае (привоз на 20, продажа на 6,3 тыс.рб.). В Железном: Великопостная ярмарка (привоз на 28, продажа на 8,7 тыс. рб.). В Гришино: Покровская ярмарка (привоз на 33 тыс.рб., продажа на 11 тыс.рб.) [20].

В 1862 году в Бахмуте состоялись ярмарки по 7 дней:

\begin{tabular}{|l|l|l|}
\hline \multicolumn{1}{|c|}{ Название } & Привоз товаров & Продано \\
\hline $\begin{array}{l}\text { Великопостная } \\
\text { с 27 февраля }\end{array}$ & 105 тыс.рб. & 75 тыс.рб. \\
\hline $\begin{array}{l}\text { Петропавловская } \\
\text { с 29 июня }\end{array}$ & 208 тыс.рб. & 90 тыс. рб. \\
\hline $\begin{array}{l}\text { Рождественобогородичная } \\
\text { с } 8 \text { сентября }\end{array}$ & 56 тыс.рб. & 41 тыс.рб. [20]. \\
\hline
\end{tabular}

После 1861 года вводится выдача специальных «гильдейских торговых свидетельств» для купцов 1 -й гильдии за 265 рублей, 2-й гильдии от 55 до 25 рублей, мелочного торга 4 классов, на развозную и разносную торговлю, для приказчиков 1 и 2 классов, для членов купеческих семей 1-й и 2-й гильдии [21].

В 1866 году в Бахмуте всех видов свидетельств выдано было 1144, город занимал 3 место в губернии по числу торговцев: 1 купец 1-й гильдии, 119 купцов 2-й гильдии, 328 приказчиков, 228 мещанремесленников [22].

В 1866 году в городе жителей 10103, домов каменных 172, деревянных 1700. На Торговой площади 48 каменных лавок, 36 временных. Купцов 3-й гильдии 140 , из других городов 17. В городе действовали 5 кирпичных, 2 мыловаренных, 7 салотопельных, 5 свечных, 2 
известковых и костопальный заводы. 5 православных церквей, католический храм, 2 синагоги (что косвенно указывает на быстрый рост численности евреев) [23].

Насчитывалось 569 ремесленники-кустарей, 744 купца при численности население 12109 человек. Общий объем прибыли от промышленности в год составлял 130 тыс. руб., от ярмарок и розничной торговли 235 тыс. руб. [22,23].

В 1866-1867 годах в Бахмуте были традиционными ярмарки: 1 -ю неделю Большого Поста (март, привезено товаров на 26,4 тыс. руб. Серебром); 21 мая, Константиновская -(товаров на 89,2 тыс. руб.); 29 июня, Петро-Павловская - (товаров на 460,7 тыс. руб.); 8 сентября Рождественскобогородичная (товаров на 275,1 тыс. руб.). Всего продавалось товаров на 181,5 тыс. руб. серебром, или $25-30 \%$ привоза [23].

В 1867 году социально-сословный состав населения Бахмута торговый облик: дворян потомственных 68, лиц духовных 69, почетных граждан 4, купцов 517, офицеров и солдат 386, отставных чинов 133, крестьян 3392, мещан 4493, иностранных подданных 28 [22].

Торговыми сборами облагались деревянные и кирпичные, рыбные, мясные, квасные, сенные, гончарные, хлебные, бараночные лавки.

Магазины, которые торговали мануфактурой и промтоварами, налогов не платили.

Налоги за сырье платили кирпичные и известковые заводы, солеварный завод И.П. Скараманги.

Первым Головой Бахмута с 1866 г. стал таганрогский купец Василий Ангельевич Ангелиди.

В П-й половине XIX века упоминается Георгий Карталов, который унаследовал от отца 3 каменных лавки в Торговых рядах, 3 дома. К купеческому сословию относились Лобасовы - Степан, сыновья Георгий и Николай. Они владели свечными, мыловаренным и салотопельным заводами, несколькими добротными домами в центре Бахмута, магазинами и лавками.

В середине - второй половине XIX века деревянные и каменные Торговые ряды окружили Троицкий собор с юга и севера, были одно и двухэтажными. Здесь размещалось более 100 магазинов и лавок. За пределами Гостиного Двора и Торговой площади было 7 торговых заведений [4].

В 1872 году в Бахмуте проживало 17990 жителей, было каменных домов 128, деревянных 1661, каменных магазинов 53, деревянных 77. Водкой, вином торговали 183 лица. Действовали 5 салотопельных, 4 свечных, винокуренный, табачный, пивоваренный заводы, 2 мельницы. Стоимость всего имущества города составляла 774,7 тыс.рублей. Город 
имел почтовую станцию Павлоградско-Славяносербского тракта, телеграф [24].

Одним из видов купеческого промысла стал извоз на конных станциях на трактах Бахмут-Мариуполь и Бахмут-Екатеринослав. Станции на почтовом тракте были переданы в аренду (посессию): Михайловская и Новомихайловская станции - купцу Фроиму Розенбергу (по 145 рб. с пары коней в год), Никитовская, Скотоватская и Авдевская - его брату Соломону Розенбергу (по 100 рб. с пары коней), Карловская, Чердаклинская - Стемковскому [25].

В 80-е годы XIX столетия в Бахмуте было 6 магазинов и 117 лавок, где «проводится торговля большей частью всеми предметами, необходимыми для ежедневной жизни как городских жителей, так и тех, которые живут в уезде» [26].

Следует обратить внимание, что одной из особенностей купеческого промысла была салотопельная промышленность.

В уезде выпасалось до 240 тыс.голов овец.

В 1835 году М. С. Воронцов приказал расчистить русло Донца. Министерство финансов построило пароход «Донец», второй пароход принадлежал директору Луганского завода инженеру-полковнику Н. М. Летуновскому, который обеспечивал углем стеклянный завод барона Фиркса в Ростове, Железной баркой сплавлял сало на экспорт [27].

Салотопельные заводы предоставляли $12 \%$ продукции в губернии и $4 \%$ - в Украине. Екатеринославский губернатор отмечал, что «важнейшие заводы салотопельные в городах Екатеринославе, Новомосковске, Бахмуте отпускают сало в значительном количестве за границу».

Переплавленный овечий жир паковался в «кутыри» (овечьи желудки) и поставлялся в Европу до 200 тыс.пудов в год через азовочерноморские порты [27].

Постепенно купечество переходило от периодической торговли на ярмарках к широкой круглогодичной рознично-магазинной торговле [27].

Среди еврейских купцов одним из самых богатых в Бахмуте был Иосиф Лейферов - на Базарной площади имел 5 лавок, одна в 1908 г. оценивалась в 7 тысяч рублей, дом, в котором он жил с семьей, оценен в 5.4 тысяч рублей [4; 27].

Мануфактурой и одеждой торговали Губарев и Петренко, Карталов, наследники Липарева, Локшин, мясом Яценко, Манукалов, Рудников, колбасами - Дунич, Чертков, Бондаревский, овощами Меднев, рыбой Браверман, Еременко, своими кондитерскими изделиями Добрейцер, Машурьянц, Зехова [4;27].

Домовладельцы Харьковской, Александровской, Екатеринославской, Николаевской улиц сдавали первые этажи под магазины. Вывески, реклама служили украшением зданий в центральной части города. На серии .дореволюционных фотооткрыток видно разнообразие вывесок, которые 
содержали сведения о владельце, поставщиках товаров, ассортименте $[4 ; 27]$.

Дума возлагала на владельцев магазинов и лавок мощение тротуаров, уборку их, посадку деревьев.

Торговой рекламой были заполнены Бахмутские газеты. В «Народной газете» Г.Г. Агуф, владелец магазина часов, который существовал 25 лет и располагался в здании управы, убеждал горожан в том, что «Омега» - самые верные часы в мире («За верность хода ручаюсь, в ином случае возвращаю деньги назад»). Склад земледельческих орудий Н.П. Гушнера (по Николаевской улице) предлагал сельскохозяйственную технику от граблей до американских косилок «Диринг». Конкурирующая фирма «И.И. Найговзен и Я.С. Фридман» (по Александровской улице) предлагала брички, тачанки. Фирма «Рувим Гуревич и Сын» предлагала все от каменного угля «всех сортов» и марок до «бричек, ходов, мажар, земледельческих машин и орудий первоклассных заводов». Чугунолитейный и механический завод Общества «Ремпель и Курц» предлагал машины для производства черепицы, тротуарных плит. Магазины М. И. Штафинского предлагали мужскую одежду[4;27].

Рекламировались «железоскобяные магазины Матвея Карталова, Назария Миленкова, Ивана Опаренко», «мебельно-зеркальный магазин Общества Корсунского и Остроухова», «оптово-розничная бакалейная торговля наследников С. Д. Липарева, «винно-бакалейный магазин Д. Миганаджиева», «модно-галантерейный магазин Л. О. Мордковича», «торгово-промышленное Общество Бахмутского металлического дела строительных и рудниковых материалов», «универсальный магазин Л. М. Браславского (велосипеды, швейные машинки, граммофоны, пластинки»), «Торговый Дом А. и Р. Розенцвайга (готовая одежда мужская, женская, дитская»), «суконно-мануфактурный магазин Общества К.Г. Салтикова и Л. Г. Абазиева» [4;27].

Многие состоятельные купцы-бахмутчане, владельцы большего количества домов, превращали их в «прибыльные», сдавали квартиры в наем. Выделялся купец А.И.Токарев. Стоимость аренды и квартплата в частных домах были высоки, квартиры в них домах предназначались не для бедных (для сезонных рабочих по ходатайству комитета общественного здоровья в 1896 году построен барак). Цены были полностью доступны для людей со средним достатком - чиновников, медиков, преподавателей, разночинцев, судей и полицейских [28].

Co II-й половины XIX столетия менялся ассортимент товаров на ежегодных традиционных оптово-розничных ярмарках. В 1866 году привозили «ткани разных цен хлопчатобумажные, шелковые, бумажные, изделия медные и железные, стекло, хрусталь, фаянс, фарфоровая, глиняная и деревянная посуда, кофе, чай, бакалейные товары, рогатый скот и овцы разных пород, табуны лошадей, которые пригоняли из области 
Войска Донского, Кубанской области, Ставропольской и Таврической губерний» [20-22].

В 1896 году из всего реализованного на ярмарках товара 38\% составлял скот, лошади и овцы; галантерея, бакалея - 3\%. Продавались рыба, хлеб, землеобрабатывающий инвентарь и орудия, строительный лес и дрова, деготь, экипажи и брички, железные изделия. Даже иконы небольшими партиями [29].

В 1896 году в Бахмуте было 13 мануфактурных лавок, 52 галантерейные, 61 бакалейные, 4 винных, 6 посудных, 4 колбасных, 4 мясных, 10 хлебных, 7 кожаных, соляная, 8 готового платья, 2 табачных, 2 писчебумажных, 2 свечных, 18 водочныхых и 4 пивных.

В 1896 году на Петро-Павловской ярмарке продано товаров на 680 тысяч рублей из за «низких цен на хлеб». Оборот Богородичной в 1896 году составил 189 тысяч рублей [29].

Бахмутские ярмарки с 1895-1898 гг., как в целом по Украине и России, в связи с ростом магазинной торговли, стали приобретать все больше оптово-сельскохозяйственный характер: торговля крупным рогатым скотом, лошадьми, овцами. Сборы с ярмарки, как источник поступления в городскую казну, уменьшались: в 1896 г.- 5435 рублей, у 1899 г. - 2853 рублей [30].

До 1907 года в Бахмуте ярмарки длились по 3 дня, с 1909 года были три больших ежегодных ярмарки. Товарооборот ярмарок упал до 150 тысяч рублей. Поэтому городская Дума вынесла место для скотоярмарок в район Броваров, создав там «Конную площадь», за пребывание на протяжении дня торговец платил по 20 копеек с лошади, 12 копеек с быка или коровы, по 1 коп. за овцу [31].

В развитие экономики и производства в Бахмутском уезде вкладывали свои деньги иногородние купцы.

Купец 3 - й гильдии Степан Аристархович Иваницкий обратился к правительству с просьбой: «занимаясь в Славянске солеварением... приобрел знание в розысках в недрах земли соляных источников..., проезжал по Бахмутскому выгону... заметил в некоторых местах должны находиться такие». Бурением скважины Иваницкого в 1833 году руководил инженер Кондратьев. По просьбе Иваницкого Бахмутский магистрат выделил 4 десятины земли с арендной платой в год 12 рублей серебром. Іваницкий просил освободить от уплаты акциза на соль на протяжении 12 лет. Но проект не был реализован [32].

В 1869 году Бахмутские купцы во главе с В. А.Ангелиди обратились к правительству с просьбой о «необходимости соединить город железной дорогой с Харково-азовской линией», убеждали, что «город Бахмут был центром всей торговли уезда и части Войска Донского, оставаясь в 20 верстах от железной дороги, не мог поддержать своего бывшего значения 
и ввоз товаров уменьшился. С проведением железной дороги значение его в торговым отношении возобновится» [33].

В 1871 году таганрогский купец И.П. Скараманга заложил скважину, которая дала данные о мощном слое соли под Бахмутом. В основу проекта солеварного завода у Бахмуте были взяты заводы в Шененбеке (Пруссия), в Нанси (Франция). Подарки И.П. Скараманги привлекли к строительству внимание министра государственных имуществ графа П. А. Валуева, директора Департамента барона Г. А. Розена, горного инженера - генерала Ерофеева [34].

30 июня 1873 года городской Голова В. Ангелиди заключил договор с И.П. Скарамангой на 81 год. Скараманга получил 5 десятин земли, за что должен был платить в первые 10 лет по 200 руб. в год, потом по 300, 400, 500 в каждом десятилетии, после 30 лет - по 1000 рублей, после окончания срока контракта завод становился собственностью Думы и города. Завод Скараманги начал работать в декабре 1874 года, имел 3 скважины до 600 футов, использовали одну. Завод сначала имел 8 чренов на 2 млн. пудов соли на год. В 1881-84 годах работало 72 семьи из города, 73 из Луганской, Зайцевской, Звановской, Покровской, Камышевахской, Лисичанской волостей, 24 из Павлоградского, Екатеринославского, Ростовского, Словяносербского уездов, 172 семьи из Курской, Калужской, Харьковской и других губерний [34].

14 марта 1874 года Александр II-й издал Указ о строительстве Донецкой железной дороги. Министр МПС генерал Посьет добился передачи в концессию московскому купцу С. И. Мамонтову ветки через Бахмут из Попасной на Краматорск по цене 44 тысяч рублей за версту [27].

Купцам В. А. Ангелиди и И.П. Скараманге железная дорога была нужна для вывоза продукции солеварного завода. 17 мая 1876 года проект Бахмутской ветки был утвержден технико-инженерным Комитетом министерства путей сообщения, рассмотрен П. А. Валуевым. Проезжая через Бахмут в 1876 году, Валуев потребовал от В. А.Ангелиди описание скважин и выводы геологов, которые работали по приглашению И.П. Скараманги. По указанию министра была продолжена железнодорожная ветка от Ступок к околице Бахмута, что позволило построить стекольный, кирпичный, алебастровый, огнеупорный заводы Фарке, первый железнодорожный вокзал [35].

На строительстве железнодорожной ветки от станции Краматорска на Попасную и Лисичанск было потрачено 2,3 млн. пудов рельсов из-за границы, С.И.Мамонтов оплатил 840 тыс. руб. пошлины ассигнациями в 1877 году. 1 декабря 1878 года первая железная дорога в Бахмут была открыта для движения. В. А. Ангелиди отмечал заслуги министра - «этой милостию мы и городское население исключительно обязаны Вам» [36].

Голова Бахмутской городской Думы купец 2-й гильдии Иосиф Михайлович Клейменов в 1876 г. предпринял попытку добычи около сел 
Покровське, Ново-Званівка, Медной Руды медных руд. 12 декабря 1879 г. Клейменов составил с крестьянами Калиновки Троицкой волости договор на аренду по 5 дес. земли под медные рудники и медеплавильный завод на 40 лет: 500 рб. за разведки и 200 рб. за рудник. В Троицком поиск медной руды длился 8 лет с 1875 до 1883 гг. В окресностях Бахмута разведка велась с 1876 г. Медная руда была найдена в х. Горелый Пень (Бойков яр), в с. Пилипчатино (Кислый Бугор).

И.М.Клейменов построил в с. Калиновка медеплавильный завод по проекту горного штейгера Билоусова с печами Рашета. Добыча медной руды достигала 300 тыс. пудов в год. Однако завод приносил убытки, немецкий «эксперт» Альдольф Рен помог завод закрыть...

С 1869 по 1880 годы в Бахмуте существовал пивоваренный завод купца Адельмана с годовым доходом в 3450 руб. В 1880 году был куплен купцом из Западной Украины А.Я. Абрамовичем. Завод выпускал пиво столовое, пльзенское, черное. Для производства продукции использовался польский ячмень в количестве 12 тыс. пудов на 6 тыс. руб. Этот ячмень доставлялся по железной дорогое из Дубно, Люблина и Варшавы. Доставлялся ячмень из Нюрнберга и Баварии на сумму 2 тыс. руб. Пивоваренный завод имел «биологическую очистку». Производством заведовал мастер- чех из Школы пивоваров в Тритте в Австрии. Пиво и мед продавались аптекам мелким оптом, в розницу - в Бахмуте, большая часть вывозилась по железной дороге [37].

Паровая мельнице Торгового Дома А.Я. Абрамовича успешно работала с 1894 года и производила 7 сортов муки. На мельнице было занято 34 рабочих, годовой оборот предприятия составлял 500 тыс. руб., была оснащена 2 паровыми котлами, существовало небольшое по объему производство макарон, что составляло 4,5\% общего производства [38].

Пиво-медоваренный завод купца 1-й гильдии Соломона Иосифовича Трахтерова был основан 9 июля 1896 года. Уставный капитал составлял 300 тыс. руб. В 1898 году завод выпускал 13570 ведер пива и 450 ведер меда на сумму 8585 рб. Производством заведовал Альберт Францевич Ебер - дипломированный пивовар из Праги. Профилирующими работниками считались: бондарь, бродильщик (два помощника бродильщика), подвальный, кочегар, солодовник (3 помощника солодовника), 3 дробильщика солода, 2 сушарщика солода. Продукцию фасовали в стеклянные бутылки 3 мойщика бутылок и 2 укупорщика [39].

В 1891 г. купец В.Г. Французов обратился в Бахмутскую городскую управу за разрешением на строительство мельницы на собственном участке. Паровую мельницу ему запрещено было строить «в виду того, что может представиться от подобного устройства опасность в пожарном отношении для деревянного здания склада военного имущества, оружия и патронов, ввиду беспокойства для местных обывателей от дыма и шума, 
которыми сопровождалось бы производство на мельнице». Французов обратился в Губернское Правление и получил разрешение.

С.И.Трахтеров построил капитальную паровую мельницу во дворе собственного дома 5 июля 1896 года. Уставной капитал составлял 450 тыс. рублей, акции - по 450 руб., один человек имел право не более чем на 10 \% акций. С. Трахтеров хлопотал перед правительством о создании первого в Бахмуте акционерного Общества — «Бахмутского мукомольного дела». 26 апреля 1896 г. Николай II благословил купца резолюцией «согласен» [40].

В 1890 году значилась паровая мельница купца Гинзбурга.

В Бахмуте к началу 80-х годов среди 1130 купцов было евреев 494, среди 8898 мещан евреев 551 [41].

Владели купцы 124 домами, евреи 44, мещане 400, евреи 54. Можно предположить, что евреи в бурно развивающейся промышленности Донбассе четко ориентировались на торговую деятельность и составляли существенную конкуренцию купцам других национальностей [41].

Купцы-евреи составляли 80-90 \% владельцев мукомолен, мастобоен, кожевенных, колбасных, мыловарных, кирпично-черепичных и алебастровых заводов, типографий и фотоателье Донбасса [41].

Бахмутскому купечеству не чужды были веяния времени-они участвовали в благотворительных лотереях для бедных учащихся, приютов, состояли попечителями учебных заведений, участвовали в концертах музыкально-драматического Общества. Шикарно развлекались в Коммерческом Клубе, где полиция их заставала за игрой в карты [42].

Таким образом, Бахмутскому купечеству уездной столицы Донбасса принадлежала огромная роль в экономике. Территория уезда составляла 8.106 квадратных верст (1 квадратная верста $=1,138$ км.), уезд делился на 22-24 волостей, было 281 сельских общин, 1 город - Бахмут, 931 разных поселений. Юзовка по промышленному потенциалу, населению превышала центр уезда. Поселки Горловка, Енакиево, Гришино давали значительные доходы земского бюджета, но до июля 1917 г. управлялись заводской администрацией, это тормозило социально-экономическое развитие. Население росло стремительными темпами: в 90-е гг. ХIX столетия в Бахмутском уезде проживало 200.177 тысяч человек, в 1915 г. численность населения достигла 560.400 тысяч. Плотность населения составляла 69 жителей на одну квадратную версту.

Выводы и перспективы дальнейших исследований. Продолжением работы над темой может быть исследование роли купечества в развитии соляной, угольной, металлообрабатывающей, химической промышленности, строительстве железных дорог Донбасса, влияние на политику органов земского самоуправления, отношение к крупному землевладению. 


\section{ЛИТЕРАТУРА} $-540 \mathrm{c}$.

1.Куромі Г. Свобода і терор у Донбасі/ Г.Куроми, - К:Основа, - 2002,

2.Оглоблин А.П. Архив Бахмутских и Торских соляных заводов// Архивное дело /А.П.Оглоблин, - № 9-10, - Харьков, - 1929.

3.Ляшенко В.Г. Торгово-промышленная буржуазия Донбасса в 18611917 гг//Летопись Донбасса /В.Г.Ляшенко, - вып. I, - Донецк, - 1991.

4. Татаринов С.Й., Тутова Н.О. Нариси історії самоврядування в Бахмуті і повіті в XVIII-XX століттях/С.Й.Татаринов, - Артемівськ, 2008. $-240 \mathrm{c}$.

5.Ведомость, учиненная в Бахмутской управе благочиния, с которого времени город Бахмут возымел свое начало, кто оного был основателем и имеет ли оный какия привилегии и герб и о прочем значит ниже, июля 20 дня 1786 г. //Центральна наукова бібліотека НАН України ім. В.Вернадського. Інститут рукописів, - Ф. 5, - оп. 1, - Спр. 492, - Арк. 144; Пірко Василь Олексійович. Заселення південно-східної України у XVI-XVIII ст./В.О.Пірко, - Донецьк, - 2000.

6.Записки русского исторического общества. Наказы в Екатерининскую комиссию по составлению нового уложения. От граждан Бахмута. - СБП, - т.144

7.Епископ Гавриил (Бадони-Банулеску). Отрывок из повествования о Новороссийском крае /Гавриил // Записки Одесского об-ва истории и древностей. - т.3. - Одесса, - 1853; Скальковский А. Соляная промышленность в Новороссийском крае/А.А.Скальковский // Журнал МВД, - ХХУ, - СПБ, - 1848.

8. Шабельский П. Историческое описание реки Северный Донец близ Святых гор/П.Шабельский // Записки Одесского Общества истории и древностей. - Одесса, - 1846.

9. Скальковский А. Опыт статистического описания Новороссийского края/А.Скальковский, - Т.1-2, - Одесса, - 1850 - 1853.

10.Описание атласа Новороссийской губернии. - СПб, - 1799.

11.Статистическое описание городов и посадов Российской империи. - СПБ, - 1825 ; Новицкий Я.П. Описание границ и городов бывшей Азовской губернии /Я.П.Новицкий. - Александровск, - 1910.

12. Мурзакевич Н.Н.. Очерк успехов Новоросскийского края в истекшие 20 летие с 1820 по 1846 годы /Н.Н.Мурзакевич. - Одесса, -1846.

13.Военно-статистическое обозрение Российской империи. - Т.X1, ч.4 - Екатеринославская губерния. - СПБ, - 1850.

14.Новороссийский календарь. -Одесса, - 1839.

15.Новороссийский календарь. - Одесса, - 1846. 
16. Статистические таблицы о состоянии городов Российской империи, Великого Княжества Финляндского и Царства Польского, составленные статистическим отделением Совета МВД. - СПб, - 1842

17.Новороссийский календарь. - Одесса, - 1853.

18. Материалы для географии и статистики России, собранные офицерами Генерального Штаба: Екатеринославская губерния. //Составил Генерального Штаба капитан В.Павлович. - Санкт-Петербург: Типография Департамента Генерального Штаба, - 1862, - с.259-280.

19. Лисенков А.В. Историко-статистическое описание Бахмутского собора /А.В.Лисенко //Екатеринославские епархиальные ведомости. - №№ 13-15, Екатеринослав, - 1875.

20. Отчет Екатеринославского губернатора за 1861 г. - РГИА. - Ф. 1281. - Оп. 5. - Д. 58; Памятная книжка Екатеринославской губернии на 1861 год. - Екатеринослав; Екатеринославская губерния. Таганрогское градоначальство. Центральный статкомитет МВД. - СПБ, - 1863; Географическо-статистический словарь Российской империи В.Семенова. - СПБ, - 1863; Новороссийский календарь. - Одесса, - 1862-64 гг.

21.Памятная книжка Екатеринославской губернии на 1864 год. Екатеринослав; Ведомость города Бахмута за 1865 год из отчета Екатеринославского губернатора. - РГИА. - Ф. 1281. - Оп. 7. - Д. 51. 22; Памятная книжка Екатеринославской губернии на 1867 год. Екатеринослав.

22.Новороссийский календарь.- Одесса, - 1866.

23. Журналы заседаний Бахмутского уездного собрания. - Бахмут, 1867, - 119 c.

24. Новороссийский календарь. - Одесса, - 1872; Отчет Екатеринославского губернатора за 1872 г. - РГИА. - Ф. 1284. - Оп. 69. Д.186.

25.Результаты торгов на сдачу земских станций в Бахмутском уезде на трехлетие с 1-го января 1884 г. по 1- января 1887 года. - Бахмут, - 1883, $-21 \mathrm{c}$.

26. Доклады управы за 1880 год XVI очередному Бахмутскому земскому уездному собранию. - Бахмут, - 1881; Отчет Екатеринославского губернатора за 1882 г.; Обзор Екатеринославской губернии за 1881 г. Приложение к нижайшему докладу Е.И.В. - РГИА. - Ф. 1284. - Оп. 223. Д. 91; Обозрение Екатеринославской губернии за 1881 год. Екатеринослав, - 1881, - 72 с.; Сборник статистических сведений по Екатеринославской губернии. Бахмутский уезд. - Екатеринослав, - 1886, T.2.

27.Третьяков К.М., Татаринов С.Й. Нариси історії економіки та промисловості Донбасу К.М.Третьяков. - Артемівськ, - 2010, - 134 с.

28. Отчет Бахмутской городской управы за 1896 год. - РГИА. - Ф. 573. - Оп.30. - Д. 1010; Смета доходов и расходов по Бахмуту за 1896 год. - 
РГИА. - Ф. 573. - Оп. 30. Д. 1008; Опросный листок о состоянии г. Бахмута в 1896 году. - РГИА. - Ф. 1290. - Оп. 11. Д. 612.

29. Ведомость об оборотах на ярмарках г. Бахмута за 1894 год. РГИА. - Ф. 1284. - Оп. 223. - Д. 150.

30.Отчет Бахмутской городской управы за 1899 г. - РГИА. - Ф. 1288. - Оп. 6. - Д. 84

31. Отчет Бахмутской городской управы за 1907 г. - Бахмут, - 1908, $105 \mathrm{c}$.

32. Об устройстве солеваренных заводов, - 1845 г. - ХОГА. - Ф.3. Оп.141. - Ед.хр. 147, 166, 629.

33. Дело об установлении в пользу доходов г. Бахмута сбора с товаров. - - РГИА. - Ф. 1288. - Оп.25. - Д. 18

34.Татаринов С.Й., Степаненко О.М. Історія соляної промисловості Донбасу /С.Й.Татаринов. - Донецьк:Кальміус, - 2013, - 75 с.

35.. Докладные записки Бахмутского купца Ангелиди в МПС за 1875 год о железной дороге Бахмут. - РГИА. - Ф. 262. - Оп. 1. - Д. 2017

36. Журнал техническо-инспекторского комитета железных дорог МПС от 17 июня 1876 г. о проведении изысканий для строительстав железной дороги через Бахмут. - РГИА. - Ф. 262. - Оп. І. - Д. 2017.

37.. Ведомость о состоянии пиво-медоваренного завода Торгового дома наследников А.Я. Абрамовича в 1895 г. - РГИА. - Ф. 20. - Оп. 12. - Д. 52

38. Первая всеобщая перепись населения Российской империи 1897 года. - т.13, - Екатеринослав, - 1904.

39.. Ведомость о состоянии пиво-медоваренного завода Трахтерова. - РГИА. - Ф. 20. - Оп. 12. - Д. 53; Дело об учреждении "Общества пивомедоварения в Бахмуте". 1895-1912 гг. - РГИА. - Ф.22. - Оп.4. - Д.95

40..Дело об учреждении "Бахмутского общества мукомольного дела". 1895-1901 'гг. - РГИА. - Ф. 22. - Оп. 4. - Д. 94

41. Оршанский. И.Г. Евреи в России /И.Г.Оршанский. - СПБ, - 1877; Татаринов С.И., Федотов С.А. Штетл Бахмут. Феномен еврейского народа в Донбассе /С.И.Татаринов. - Харьков:Слово, - 2013, - 185 с.

42. Азартные игры в Коммерческом клубе. - Дн.ОГА. - Ф.11. - Оп.1. - Д.1032

Условные сокращения:

РГИА- Российский государственный исторический архив (Петербург) 